\title{
REVIEW
}

\section{Psychological impact of genetic testing for Huntington's disease: an update of the literature}

\author{
Bettina Meiser, Stewart Dunn
}

\begin{abstract}
Genetic testing has been available for Huntington's disease for longer than any other adult onset genetic disorder. The discovery of the genetic mutation causing Huntington's disease made possible the use of predictive testing to identify currently unaffected carriers. Concerns have been raised that predictive testing may lead to an increase in deaths by suicide among identified carriers, and these concerns set in motion research to assess the psychological impact of predictive testing for Huntington's disease. This review article provides an overview of the literature and draws implications for clinical practice. About $10 \%-20 \%$ of people at risk request testing when approached by registries or testing centres. Most of the evidence suggests that non-carriers and carriers differ significantly in terms of short term, but not long term, general psychological distress. Adjustment to results was found to depend more on psychological adjustment before testing than the testing result itself. Although risk factors for psychological sequelae have been identified, few adverse events have been described and no obvious contraindications for testing people at risk have been identified. The psychological impact of testing may depend on whether testing was based on linkage analysis or mutation detection. Cohorts enrolled in mutation detection programmes have higher levels of depression before and after testing, compared with people who sought genetic testing when linkage analysis was available. There is evidence that people who choose to be tested are psychologically selected for a favourable response to testing. The impact of testing on people in settings where less intensive counselling protocols and eligibility criteria are used is unknown, and genetic testing is therefore best offered as part of comprehensive specialist counselling.

(F Neurol Neurosurg Psychiatry 2000;69:574-578)
\end{abstract}

Keywords: Huntington's disease; psychological adjustment; genetic testing
The frequency of Huntington's disease in populations of European descent is between three and seven affected people per 100000 population. ${ }^{1}$ The mean age of onset of Huntington's disease is 40 years, with a mean duration of 15 years. ${ }^{1}$ About $98 \%$ of patients with Huntington's disease have an expansion of a trinucleotide (CAG) repeat on the Huntington gene. ${ }^{1}$ No medical treatments to delay onset of disease or prophylactic strategies are available. The discovery of a genetic marker for Huntington's disease in 1983 made possible the use of linkage analysis to identify currently unaffected carriers with a sensitivity of about $96 \%-99 \%$. $^{2}$ Linkage analysis takes advantage of the spatial proximity of a marker and a mutation and requires blood samples from both affected and unaffected family members over several generations. The nature of linkage analysis is probabilistic, because genetic recombination can occur between markers and the gene during meiosis. Most carriers and non-carriers were given risk estimates of $90 \%$ or more and $10 \%$ or less respectively, reflecting the relatively low accuracy of these earlier linkage studies. Since identification of the responsible gene mutation in $1993,{ }^{3}$ direct mutation detection methods have been applied, leading to highly accurate predictive testing with a sensitivity and specificity of virtually $100 \%$.

Compared with other dominantly inherited genetic traits leading to adult onset disorders, predictive testing for Huntington's disease has been offered for the longest time. ${ }^{4}$ Carriers will definitely get the disease- that is, Huntington's disease confers $100 \%$ penetrance, which refers to the proportion of carriers of a genetic alteration who will manifest the effects of it and is equivalent to lifetime incidence. Non-carriers definitely will not develop the disesae.

When linkage analysis first became available, concerns were raised over the possibility of predictive testing leading to an increase in deaths by suicide among identified carriers. Suicide has long been recognised as a serious consequence of Huntington's disease. One carefully designed study reports a fourfold increase in the suicide rate among people affected compared with the rate of the general white population in the United States. ${ }^{5}$ Attitudinal surveys of people at risk suggest that between $11 \%$ and $33 \%$ considered suicide a 
possible response in the future. ${ }^{6}$ These data highlighted the need for research to identify predictors of depression and suicidal intention in people entering predictive testing programmes for Huntington's disease. The identification of the genetic marker prompted a considerable amount of research on attitudes to, and the psychological impact of, testing for the disease.

\section{Attitudes to genetic testing for \\ Huntington's disease}

Methodological aspects and major findings of intention to test surveys of people at risk carried out since the genetic marker was identified, but before mutation analysis became available, are summarised in table 1.

Between $40 \%$ and $79 \%$ of people at risk of developing Huntington's disease reported intention to use the test. Interest in genetic testing was found to be negatively associated with being married, and positively correlated with the number of affected relatives and earlier parental age of onset of Huntington's disease. ${ }^{6}$ The most commonly reported reasons for wanting to be tested were: to be certain, to plan for the future, and to inform children. ${ }^{6} 13$

Data on actual uptake of testing suggest that uptake has been much lower than suggested by attitudinal surveys. The percentage of people at risk who requested testing when approached by registries or testing centres varied from $9 \%$ in Wales, $10 \%$ in Indiana, $16 \%$ in the Manchester area, to $20 \%$ in the Vancouver area. ${ }^{14}$ On the basis of the relatively low rate of uptake, it is likely that people who chose to be tested are not representative of the Huntington's disease population as a whole. ${ }^{15}$

People who decide to have the test are more likely to have higher educational levels than the general population, and women tend to be overrepresented, ${ }^{16}$ possibly reflecting women's traditionally greater involvement in reproductive decisions or concern for existing children. ${ }^{17}$

\section{Self selection for favourable psychological response}

Several studies have provided evidence that people who choose to be tested are psychologically selected for a favourable response to testing. People who reported being at risk of suicide or anticipated feeling depressed should the result be positive were significantly less likely to want the test, compared with those not anticipating suicidal or depressive feelings. ${ }^{69}$ The most commonly reported reasons for choosing not to have the test related to the emotional and psychological consequences of a positive test result-such as fear of searching for symptoms and of losing what hope could be retained. ${ }^{14}$ Other reasons for choosing not be tested were: increased risk to children if found to be a carrier, absence of an effective cure, and potential loss of health insurance. ${ }^{18}$

Compared with test recipients, people who declined testing were found to be significantly more depressed and pessimistic. ${ }^{19}$ They were more likely to expect to be carriers and anticipated more negative effects from a positive result. ${ }^{19}$ Interestingly, people who declined were more likely to have learned about their being at risk for Huntington's disease during adolescence, rather than adulthood. ${ }^{19}$

Studies that compared psychological characteristics of people who had enrolled in a linkage testing programme with those of the general population found that psychological adjustment was comparable. ${ }^{17}$ However, people at risk were found to be more resourceful than the general population. ${ }^{17}$ Mean anxiety and depression scores were found to be lower than means for the general population, and test applicants had significantly higher ego strength and were more socially extroverted. ${ }^{20}$

The evidence on self selection for a favourable response of people who choose to have the test suggests that findings of studies on the psychological impact of genetic testing for Huntington's disease may not be generalisable to the population of people at risk of Huntington's disease at large. It has been suggested that those who are best equipped emotionally to deal with the information opt for genetic testing. ${ }^{21}$ Alternatively, it is possible that those who are psychologically more vulnerable do not follow through the typically rigorous counselling and testing protocols.

Generalisability to settings where less intensive counselling protocols and eligibility criteria are used is also limited, given that all psychological impact studies reviewed were conducted as part of carefully designed research programmes with comprehensive counselling. ${ }^{4}$ People with less ego strength might have experienced considerable psychological support through these often extensive programmes of counselling before and after testing.

\section{Differences in impact of testing between} linkage analysis and mutation detection There is evidence that cohorts enrolled in direct testing protocols since 1993 have higher levels of depression before testing, compared with people who sought genetic

Table 1 Overview of studies on attitudes to genetic testing for Huntington's disease

\begin{tabular}{|c|c|c|c|}
\hline Study & Sample & $n$ & $\begin{array}{l}\text { Rreporting intention } \\
\text { to use test }(\%)\end{array}$ \\
\hline Schoenfeld et al $1984^{7}$ & $21 \mathrm{Men}$ and 34 women at $50 \%$ risk & 55 & 73 \\
\hline Evers-Kiebooms et al, $1987^{8}$ & 41 people at $50 \%$ risk, eight at $25 \%$ risk & 49 & 57 \\
\hline Evers-Kiebooms et al, $1989^{9}$ & 51 Men and 53 women, $82 \%$ at $50 \%, 18 \%$ at $25 \%$ risk & 104 & 66 \\
\hline Kessler et al $1987^{10}$ & 27 Men and 42 women at $50 \%$ risk of $\mathrm{HD}$ & 69 & 79 \\
\hline Markel et al $1987^{11}$ & 52 Men and 103 women at $50 \%$ risk & 155 & 63 \\
\hline Mastromauro et al $1987^{6}$ & 56 Men and 75 women at $50 \%$ risk & 131 & 66 \\
\hline Meissen et al $1987^{12}$ & 21 Men and 35 women at $50 \%$ risk & 56 & 65 \\
\hline Jacopini et al $1992^{13}$ & 27 Men and 30 women, $86 \%$ at $50 \%, 14 \%$ at $25 \%$ risk & 57 & 40 \\
\hline
\end{tabular}


testing when linkage analysis was available. ${ }^{22}$ The psychological impact of testing may depend on whether testing was based on linkage analysis or mutation detection. Published studies include people tested by linkage, ${ }^{23}$ or mutation detection, or a combination of both. Only one study permits a comparison of the impact of different testing strategies. ${ }^{24}$ People tested by mutation detection had higher depression scores 12 months after disclosure compared with those tested by linkage. ${ }^{24}$ Several reasons for the differences in psychological adjustment between the cohorts have been suggested. People who present for linkage testing may have had greater social support before testing than those who do not have "to orchestrate a family-wide effort to collect the blood samples required for Huntington's disease linkage testing". ${ }^{24}$ Alternatively, the need to call on other family members for participation in linkage testing might lead to improved family communication and hence support. Finally, the risk information presented during genetic counselling within the context of linkage testing may account for the effect. ${ }^{24}$ Carriers may have been consoled by knowing that there is a $1 \%$ chance that they are not carriers, ${ }^{24}$ thereby providing increased scope for optimism bias $^{25}$ and its protective effects on mental health. ${ }^{26}$

\section{Psychological impact of genetic testing for Huntington's disease}

Table 2 presents a summary of methodological aspects and major findings of prospective studies that used standardised measures of psychological outcome and evaluated the psychological impact of genetic testing for Huntington's disease..$^{23} 27$ The table indicates which studies were based on linkage and which on mutation analysis and presents results of significance tests between carriers and noncarriers 7-10 days and 12 months after disclosure. For ease of comprehension, people who underwent linkage analysis and received increased risk results will be referred to as carriers and those with decreased risk results as non-carriers. Carriers and non-carriers differed significantly on all psychological out- come measures at the 7-10 days, but not the 6 months and 12 months of follow up. ${ }^{23}{ }^{28}$ However, the study based on the largest sample size to date measured hopelessness as a dimension of particular relevance to the population of people at risk and found that differences between carriers and non-carriers may persist long term. ${ }^{24}$ This finding raises some concern about this particular population, given that hopelessness has been identified as a predictor of suicide. ${ }^{29}$

The analysis of scores before, compared with after, receiving the test result (results not shown in table 2) indicates that psychological adjustment of non-carriers either tends to be unaltered $^{24} 28$ or improves after receipt of the result. $^{2327}$ Some studies found no significant changes from baseline on any follow up measures for carriers, ${ }^{23} 2427$ whereas others found short term increases in hopelessness.

One study used a control group design and showed that people at risk who did not receive a genetic testing result had higher scores for depression and lower scores for wellbeing at the 12 month follow up, compared with both carriers and non-carriers. ${ }^{23}$ The authors conclude that receiving a test result leads to psychological benefits, even if it indicates carrier status, by reducing uncertainty and providing an opportunity for appropriate planning.

Baseline levels of depression or hopelessness (rather than the test result itself) were found to be the best predictors of levels of hopelessness and intrusive thoughts after disclosure. ${ }^{24} 30$ People who were married, had no children, and were closer to their estimated ages of onset of Huntington's disease were found to be less well adjusted at all times. ${ }^{24}$

An unexpected finding was that a small proportion of non-carriers who received a low risk result experienced serious difficulties in coping with their new genetic status. ${ }^{31}$ In depth interviews showed that having made irreversible decisions based on the belief that they would develop Huntington's disease or overly optimistic expectations of the positive effects of a decreased risk were contributing factors. Survivor guilt - that is, guilt feelings relative to other family members who tested positive or those

Table 2 Studies on the psychological impact of genetic testing for Huntington's disease

\begin{tabular}{|c|c|c|c|c|c|}
\hline \multirow[b]{2}{*}{ Study } & \multirow[b]{2}{*}{ Type of genetic test ${ }^{\star}$} & \multirow[b]{2}{*}{ Sample } & \multirow[b]{2}{*}{ Instrument $\dagger$} & \multicolumn{2}{|l|}{ Findings $\neq$} \\
\hline & & & & $7-10$ days & 12 months \\
\hline Wiggins et al $1992^{23}$ & LA & $\begin{array}{l}37 \text { Carriers } \\
58 \text { Non-carriers } \\
40 \text { No result } \$\end{array}$ & $\begin{array}{l}\text { SCL-90 } \\
\text { GWS } \\
\text { BDS }\end{array}$ & $\begin{array}{l}\text { Significantly higher } \\
\text { Significantly lower } \\
\text { Significantly higher }\end{array}$ & $\begin{array}{l}\text { NS } \\
\text { NS }\end{array}$ \\
\hline Tibben et al $1997^{32}$ & LA & $\begin{array}{l}20 \text { Carriers } \\
44 \text { non-carriers }\end{array}$ & $\begin{array}{l}\text { IES Avoidance } \\
\text { BHS }\end{array}$ & $\begin{array}{l}\text { Significantly higher } \\
\text { Significantly higher }\end{array}$ & $\begin{array}{l}\text { NS (6 Months) } \\
\text { NS (6 Months) }\end{array}$ \\
\hline Codori et al $1997^{24}$ & LA MA & $\begin{array}{l}52 \text { Carriers } \\
108 \text { non-carriers }\end{array}$ & $\begin{array}{l}\text { BDI } \\
\text { BHS }\end{array}$ & $\begin{array}{l}\text { Not available } \\
\text { Not available }\end{array}$ & $\begin{array}{l}\text { NS } \\
\text { Significantly higher }\end{array}$ \\
\hline Quaid and Wesson, $1995^{33}$ & LA & $\begin{array}{l}5 \text { Carriers } \\
14 \text { non-carriers }\end{array}$ & SCL-90 & Not available & Significantly higher \\
\hline Decruyenaere et al $1996^{27}$ & LA MA & $\begin{array}{l}22 \text { Carriers } \\
31 \text { non-carriers }\end{array}$ & $\begin{array}{l}\text { STAI } \\
\text { BDI }\end{array}$ & $\begin{array}{l}\text { NS } \\
\text { NS }\end{array}$ & $\begin{array}{l}\text { NS } \\
\text { NS }\end{array}$ \\
\hline Dudok de Wit $1997^{34}$ & MA & $\begin{array}{l}9 \text { Carriers } \\
16 \text { non-carriers }\end{array}$ & IES & NS & NS (6 Months) \\
\hline
\end{tabular}

${ }^{\star} \mathrm{LA}=$ linkage analysis; $\mathrm{MA}=$ mutation analysis.

$\dagger$ BHS=Beck hopelessness scale; BDI=Beck depression inventory; IES=impact of event scale (higher scores on these scales are equivalent to more symptoms); $\mathrm{SCL}=$ symptom check list; STAI=Spielberger anxiety inventory; GWS=general wellbeing scale.

$\ddagger$ The analyses refer to carrier $v$ non-carrier scores at each time point.

$§$ The "no result" group includes 23 testing decliners and 17 people who did not receive an informative result. 
already affected by Huntington's disease, were also found. ${ }^{31}$

IMPACT ON PARTNERS OF PEOPLE UNDERGOING GENETIC TESTING

Tibben et al also followed up partners of people undergoing genetic testing, and found that carriers' partners showed the same course of distress as carriers. ${ }^{32}$ Compared with noncarriers' partners, carriers' partners had significantly higher levels of psychological distress 1 week, 6 months, and 3 years after disclosure. ${ }^{32}$ Having children was an additional psychological risk factor for carriers' partners, who showed significantly higher scores on all psychological outcome measures both short and long term, compared with carriers' partners without children. ${ }^{32}$ These findings are similar to those of Quaid and Wesson ${ }^{33}$ and indicate that genetic testing for Huntington's disease has significant effects on partners of carriers, suggesting the need to include partners more comprehensively in psychological assessments. $^{35}$

\section{Conclusion}

Most of the evidence on the psychological impact of testing for Huntington's disease suggests that non-carriers and carriers differ significantly in short term, but not long term, general psychological distress. Carriers show either no changes from psychological adjustment before testing ${ }^{2324}$ or only short term increases in hopelessness. ${ }^{28}$ Adjustment to results was found to depend more on psychological adjustment before testing than the testing result itself. ${ }^{24} 2732$ Although risk factors have been identified, ${ }^{24}{ }^{36}$ few adverse events have been described, ${ }^{36-38}$ and no obvious contraindications for testing have been identified. ${ }^{24}$ The impact of testing on people in settings where less intensive counselling protocols and eligibility criteria are used is unknown, and genetic testing is therefore best offered as part of comprehensive specialist counselling. There is evidence that people who choose to be tested are psychologically selected for a favourable response to testing. Given the potential psychological sequelae of genetic testing in less well adjusted people, it is advisable to routinely assess levels of depression or hopelessness with formal assessment tools. ${ }^{29}$ People with high levels of depression or hopelessness may benefit from referral to liaison staff with expertise in psychiatry or clinical psychology before decision making about genetic testing.

BM is supported by Project Grant No 970929 from the National Health and Medical Research Council of Australia. We thank the reviewers for their valuable suggestions.

1 Hayden M. Basal ganglia disorders. In: Rimoin DL, Connor JM, Pyeritz RE, eds. Emery and Rimoin's principles and practice of medical genetics, 3rd ed. New York: Churchill Living-

2 Gusella JF, Wexler NS, Conneally PM, et al. A polymorphic DNA marker genetically linked to Huntington's disease. Nature 1983;306:234-9.
3 Huntington's Disease Collaborative Research Group. A novel gene containing a trinucleotide repeat that is expanded and unstable in Huntington's disease chromosomes. Cell 1993;72:971-83.

4 Benjamin C, Adam S, Wiggins S, et al. Proceed with care: direct predictive testing for Huntington's disease. Am $\mathcal{F}$ Med Genet 1994;55:606-7.

5 Farrer LA. Suicide and attempted suicide in Huntington's disease: implications for preclinical testing of persons at risk. Am F Med Genet 1986;24:305-11.

6 Mastromauro C, Myers RH, Berkman B. Attitudes toward presymptomatic testing in Huntington's disease. $\mathrm{Am} \mathrm{f} \mathrm{Med}$ Genet 1987;26:271-82

7 Schoenfeld M, Myers RH, Berkman B, et al. Potential impact of a predictive test on the gene frequency of Huntington's disease. Am f Med Genet 1984;18:423-9.

8 Evers Kiebooms G, Cassiman JJ, Van den Berghe $\mathrm{H}$. Attitudes towards predictive testing in Huntington's Attitudes towards predictive testing in Huntington's 275-9.

9 Evers Kiebooms G, Swerts A, Cassiman JJ, et al. The motivation of at-risk individuals and their partners in deciding for or against predictive testing for Huntington's disease. Clin Genet 1989;35:29-40.

10 Kessler S, Field T, Worth L, et al. Attitudes of persons at risk for Huntington's disease towards predictive testing. Am $\mathcal{F}$ Med Genet 1987;26:259-70.

11 Markel DS, Young AB, Penney JB. At-risk persons' attitudes toward presymptomatic and prenatal testing of Huntington's disease in Michigan. Am f Med Genet 1987;26:295305.

12 Meissen GJ, Berchek RL. Intended use of predictive testing by those at risk for Huntington's disease. Am $\mathcal{F}$ Med Genet 1987;26:283-93.

13 Jacopini GA, D'Amico R, Frontali M, et al. Attitudes of persons at risk and their partners toward predictive testing. In: Evers-Kiebooms G, Fryns JP, Cassiman JJ, et al, eds. Evers-Kiebooms G, Fryns JP, Cassiman JJ, et al, eds.
Psychosocial aspects of genetic counseling. New York: WileyPsychosocial aspects

14 Babul R, Adam S, Kremer B, et al. Attitudes towards direct predictive testing for the Huntington's disease gene. $\mathcal{F} A M A$ 1993;270:2321-5

15 Tyler A, Ball D, Craufurd D. Presymptomatic testing for Huntington's disease in the United Kingdom. BMF 1992;304:1593-6.

16 Craufurd D, Dodge A, Kerzin-Storrar L, et al. Uptake of presymptomatic predictive testing for Huntington's disease. Lancet 1989;8663:6035.

17 Bloch M, Fahy M, Fox S, et al. Predictive testing for Huntington's disease: II. Demographic characteristics, life-style patterns, attitudes and psychosocial assessments of the first 51 test candidates. Am 7 Med Genet 1989;32:217-24.

18 Quaid KA, Morris M. Reluctance to undergo predictive testing: the case of Huntington's disease. Am f Med Genet 1993;45:41-5.

19 Van der Steenstraten IM, Tibben A, Roos RAC, et al. Predictive testing for Huntington's disease: nonparticipants compared with participants in the Dutch program. Am f Human Genet 1994;55:618-25.

20 Decruyenaere M, Evers-Kiebooms G, Boogaerts A. Predictive testing for Huntington's disease: risk perception, reasons for testing and psychological profile of test applicants. Genet Couns 1995;6:1-13.

21 Kessler S. Predictive testing for Huntington's disease: a psychologist's view. Am f Med Genet 1994;54:161-6.

22 Adam S, Wiggins S, Lawson K, et al. Predictive testing for Huntington's disease (HD): differences in uptake and characteristics of linked marker and direct test cohorts. $A m$ characteristics of linked marker and di

23 Wiggins S, Whyte P, Huggins M, et al. The psychological consequences of predictive testing for Huntington's disease. N Engl f Med 1992;327:1401-5.

24 Codori AM, Slavney PR, Young C, et al. Predictors of psychological adjustment to genetic testing for Huntington's disease. Health Psychol 1997;16:36-50.

25 Weinstein ND. Optimistic biases about personal risks. Science 1989;246:1232-3.

26 Scheier MF, Carver CS. Effects of optimism on psychological and physical well-being: theoretical overview and empirical update. Cognit Ther Res 1992;16:201-8.

27 Decruyenaere M, Evers-Kiebooms G, Boogaerts A. Prediction of psychological functioning one year after the predictive test for Huntington's disease and impact of the test result on reproductive decision making. 7 Med Genet 1996; 33:737-43.

28 Tibben A, Duivenvoorden HJ, Niermeijer MF, et al. Psychological effects of presymptomatic DNA testing for Huntington's disease in the Dutch program. Psychosom Med 1994;56:526-32.

29 Beck A, Brown G, Berchick RJ, et al. Relationship between hopelessness and ultimate suicide: a replication with psychiatric outpatients. Am F Psychiatry 1990;147:190-5.

30 Tibben A, Duivenvoorden HJ, Vegter-van der Vlis M, et al. Presymptomatic DNA testing for Huntington's disease: identifying the need for psychological intervention. $A m$ F Med Genet 1993;48:137-44.

31 Huggins $M$, Bloch $M$, Wiggins S, et al. Predictive testing for Huntington's disease in Canada: adverse effects and unexpected results in those receiving a decreased risk. Am f Med Genet 1992;42:508-15.

32 Tibben A, Timman R, Bannink EC, et al. Three year follow up after presymptomatic testing for Huntington's disease in 35 . 
33 Quaid KA, Wesson MK. Exploration of the effects of predictive testing for Huntington's disease on intimate predictive testing for Huntington's disease
relationships. Am $\mathcal{A}$ Med Genet 1995;57:46-51.

34 Dudok de Wit AC. To know or not know: the psychological implications of presymptomatic testing for autosomal dominant inheritable late-onset disorders $[\mathrm{PhD}$ thesis]. Erasmus University Rotterdam, The Netherlands, 1997.

35 Hayes CV. Genetic testing for Huntington's disease: a family issue. $N$ Engl F Med 1992;327:1449-51.
36 Lawson K, Wiggins S, Green T, et al. Adverse psychological effects occurring in the first year after predictive testing for Huntington's disease. 7 Med Genet 1996;33:856-62.

37 Bloch M, Adam S, Hayden M. A survey of catastrophic events following predictive testing for Huntington's disease. Am F Med Genet 1996;57(suppl):A333.

38 Mlynik Szmid A. Psychological consequences of presymptomatic testing for Huntington's disease. Lancet 1997;349: 808 .

\section{HISTORICAL NOTE}

\section{Henry Head (1861-1940)}

Henry Head was born of Quaker stock on 4 August 1861 at 6 Park Road, Stoke Newington, son of an insurance broker at Lloyds. Educated at Charterhouse and Trinity College, Cambridge (1 st class in both parts of the Natural Science Tripos), ${ }^{1}$ he chose to study Medicine, influenced by his mother's cousin, Marcus Beck, who had been Joseph Lister's assistant. For a period after Cambridge, he worked with Hering on respiratory physiology in Prague, acquiring fluency in both French and German. Head returned to University College Hospital, qualifying in 1890 . He worked at Queen Square under Thomas Buzzard, and at Victoria Park Hospital for Chest Diseases, where he developed his interests in pain and in physiology. His Cambridge MD thesis, On disturbances of sensation with especial reference to the pain of visceral disease, was later published in Brain (1893). It was of outstanding merit.

He was registrar, then assistant physician at the London Hospital, where his gifts as a born teacher, impelled to impart information, brought crowds of admiring students from afar. "Henry Head doing gaits was a perennial attraction." In 1903, with the assistance of Sherren and Rivers, he made many observations on himself after sectioning the superficial ramus of his own radial nerve. He undertook this experiment because of his annoyance with the unreliability of the average sensory witness. ${ }^{2}$ The results were first published in Brain in 1908 and were widely acclaimed.

Patterns and the referral of pain led him to study herpes zoster with A W Campbell, pathologist to Rainhill County Asylum. From this his investigations of the dermatomes naturally evolved. To obtain first hand information on shingles, which was then common in his patients afflicted by general paralysis of the insane, his enthusiasm forced him to live in the hospital for 2 years recording 450 cases and 21 postmortem studies. Foerster noted the remarkable accuracy of Head's observations when compared with the method of section of nerve roots.
After his study on cutaneous sensation and dermatomes, Head's investigations were devoted mainly to the sensory system, where his original thought and skilled clinical techniques brought order out of chaos. ${ }^{4}$ His postulate of two separate sensory systemsprotopathic and epicritic - to explain the different susceptibilities of sensation, was however, severely criticised. Recent recording from single sensory neurons has partly reaffirmed Head's separation of highly differentiated sensations from other types. He did indeed provide the first rational explanation of the nature of sensory dissociation. The clinical facts and techniques, which he and his collaborators established, remain the basis for many clinical investigations of sensation today.

His extensive study of spinal reflex functions also illuminated and provoked interest in this relatively neglected area. It arose in the first world war, when he worked with George Riddoch on war injuries. They studied spinal cord injury and paraplegia yielding important papers, and knowledge that would save many such future casualties.

Brain disorders were likewise the subject of his inquiring mind. He wrote an important paper with Gordon Holmes in 1911 on sensory disturbances from cerebral lesions. His last major work, Aphasia and kindred disorders of speech, appeared in two volumes in 1926, lauded by Critchley" as "the finest monograph on the subject of aphasia in the neurological literature." Here, his originality brought critical definition to the then materialistic notions of what he scornfully described as the "diagram-makers." Describing "semantic aphasia", he provided a link between the linguistic and the intellectual aspects of speech. The full implications of this work have been credited and amplified by modern aphasiologists. His later works related to the concepts of attention and vigilance, and the idea of body image. These, and Head's notions of dynamic schemata in thought processes, which were manifest as symbolic formulation and expression, were well in advance of his time.

His writings $s^{5}$ include a volume of attractive verse, The destroyers. He was the author of Allbutt's System of Medicine, and he edited Brain from 1910 to 1925.

Head's singular merit ${ }^{5}$ was rewarded by the Marshall Hall medal of the Royal Medical and Chirurgical Society in 1903, the Royal
Medal of the Royal Society in 1908, and the Moxon Medal of the Royal College of Physicians in 1927. To the College, he delivered the Goulstonian Lectures in 1901 and the Croonian Lectures in 1911, and, to the Royal Society, the Croonian Lecture of $1921 . \mathrm{He}$ was knighted in 1927 .

Undoubtedly Henry Head is to be rated as one of England's great neurologists: a diligent and inspiring teacher, bubbling over with new ideas, he combined a scientific and critical approach with a vivid, if at times overworked imagination. He was a generous man of rotund figure, with a Van Dyke beard and a high pitched voice.

He married Ruth Mayhew, headmistress and author, in 1904, and they worked together on her literary works and on his poetry, with mutual devotion. His interest in the arts, music and humanity were wide and deep; he could discourse on topics from Goethe to Guardi or Mozart without effort. Robert Nichols wrote about him in The Times:

"He had Leonardos' lofty human compassion, humility, patience, and profound serenity of spirit."

After the onset of Parkinsonism in 1919, he retired in 1925 to live in Dorset and then Reading. Even in this period, his lively mind and indomitable enthusiasm immensely stimulated the fortunate few who were privileged to enjoy his conversation. He eschewed all drug therapy, fearful that solanaceous drugs would impair his mind. He died on 9 October 1940, immobilised by illness, just able to talk, but mentally active. His fortune, he left to medical science, the Royal Society acting as legatee.

J M S PEARCE 304 Beverley Road, Anlaby, Hull HU10 7BG, UK jmspearce@freenet.co.uk

1 Brain R. Doctors past and present. London: Pitman, 1964:100-7.

2 Critchley M. The black hole and other essays. London, Pitman, 1964:98-107.

3 Head H, Campbell AW. The pathology of herpes zoster and its bearing on sensory localization. Brain 1900;23:353-529.

4 Henson RA. Henry Head: his influence on the development of ideas on sensation. Br Med Bull 1977;33:91-6.

5 Brain R. Henry Head: the man and his ideas including Head's bibliography]. Brain 1961; 84:561-71. 